\title{
Determinants of Consumers' Intentions towards the Purchase of Energy Efficient Appliances in Pakistan: An Extended Model of the Theory of Planned Behavior
}

\author{
Muhammad Rizwan Ali ${ }^{1}$, Muhammad Shafiq ${ }^{2, *}$ and Murad Andejany ${ }^{3}$ \\ 1 Department of Industrial Engineering, University of Engineering and Technology, Taxila 47080, Pakistan; \\ engralimrizwan@gmail.com \\ 2 Department of Industrial Engineering and Management, University of the Punjab, Lahore 54590, Pakistan \\ 3 Department of Industrial and Systems Engineering, University of Jeddah, Jeddah 23452, Saudi Arabia; \\ mbazzar@uj.edu.sa \\ * Correspondence: shafiqaatir1@gmail.com
}

Citation: Ali, M.R.; Shafiq, M.; Andejany, M. Determinants of Consumers' Intentions towards the Purchase of Energy Efficient Appliances in Pakistan: An Extended Model of the Theory of Planned Behavior. Sustainability 2021, 13, 565. https://doi.org/10.3390/su13020565

Received: 25 December 2020

Accepted: 4 January 2021

Published: 8 January 2021

Publisher's Note: MDPI stays neutral with regard to jurisdictional clai$\mathrm{ms}$ in published maps and institutional affiliations.

Copyright: (C) 2021 by the authors. Licensee MDPI, Basel, Switzerland. This article is an open access article distributed under the terms and conditions of the Creative Commons Attribution (CC BY) license (https:// creativecommons.org/licenses/by/ $4.0 /)$.

\begin{abstract}
Amplified energy demand due to technologically advanced electrical and electronic appliances has accentuated the importance of energy efficiency to overcome energy shortage and environmental concerns. As adoption of energy efficient appliances depends on perception of the consumers, this study focuses on behavioral exploration of the consumers' intentions towards the purchase of energy efficient appliances using an extended model of the theory of planned behavior (TPB). The study is based on a survey comprising 289 respondents. Partial least square (PLS) method is used to analyze the data. The results show that the attitude, perceived behavioral control, policy information campaigns, and past-purchase experiences significantly impact behavioral intentions of the consumers, whereas subjective and moral norms are insignificant in shaping behavioral intentions. Based on analyses, policy implications emphasizing (i) strong awareness campaigns, (ii) energy efficiency incentives, and (iii) replacement initiatives are proposed to help policy makers and administrators in achieving required goals of energy efficiency and conservation. The proposed research model and policy initiatives are a blueprint for synergies among policymakers, practitioners, and researchers in understanding and shaping consumers' behaviors towards the purchase of energy efficient products, particularly, in developing countries.
\end{abstract}

Keywords: energy efficiency; purchase intentions; theory of planned behavior; energy efficient appliances; Pakistan

\section{Introduction}

Sustainable energy strategies mainly focus on improvements towards: increased generation efficiency, reduced dependency on fossil fuels, and an efficient energy consumption [1]. The residential sector is one of the significant contributors in global energy consumption and $\mathrm{CO}_{2}$ emissions, representing a share of $27 \%$ and $17 \%$, respectively [2]. Particularly, the residential sector of developing economies has witnessed an incessant rise in electricity demand due to rapid electrification and swift increase in the number of consumers. For instance, India provided electricity access to half a billion people between 2001 and 2016, leading to $24 \%$ share of the residential sector in the country [3]. Similarly, in Bangladesh, the electricity consumption in the household sector grew by $48 \%$ from 2010 to 2015. The sector accounts for $52 \%$ of the total electricity consumption in the country [4]. In addition, the energy demand of the residential sector has also increased due to higher adoption of technologically advanced electrical and electronic appliances [5]. Because of its significant share, considerable attention has been given to the residential sector in policies to overcome the issues of fuel security, dependency on fossil fuels, and climatic changes. The prime focus of these policies was to devise energy saving programs including 
promotion of energy efficient (EE) technologies, energy efficiency labels, and standards for household electrical appliances [6].

Energy saving in the residential sector depends on behavior of the consumers in terms of technological choices and habitual actions. Technological choice mean whether the consumers prefer to purchase energy efficient or traditional appliances, whereas habitual actions mean day-to-day actions towards energy usage such as turning-off appliances while not being in use [7]. The adoption of energy efficient appliances (EEA) contributes more in terms of energy efficiency and sustainability in comparison with habitual actions. Additionally, it is a one-time investment and does not require continuous effort of the consumers [8].

Consumers green purchase behavior and pro-environmental behavior has been a major area of interest for policy makers and researchers particularly in developed countries [9]. However, in recent years, the studies concerning consumers' behaviors towards efficient utilization and energy conservation has recently drawn more attention among developing and populated countries because of an increasing energy deficit and environmental concerns. For instance, energy saving and green purchase behavior has been well studied in China [10-12], India [13], and Malaysia [14]. The government and policy makers in developing countries are trying to identify the best ways to better understand consumers perspective in order to design effective energy saving strategies.

Pakistan has been among ten energy deficient countries for a couple of decades [15]. The shortage of energy has severely affected the economic growth of the country for years. Due to structured efforts of government, electricity generation has increased significantly, however, electricity demand is on an incessant rise. The increase in energy demand is due to a continuous increase in the number of consumers, specifically, the householdconsumers increased from 19,323 million in 2015 to 21,991 million in 2017. In addition, the household sector in developing countries such as Pakistan nearly accounts for half of the total energy consumption and is expected to rise further in the future [16]. The increasing energy demand and required investment to meet this demand intensifies the necessity of improving the energy efficiency on the distribution side, particularly on the consumers' end.

Following the global energy efficiency and conservation efforts, the government of Pakistan (GoP) has also initiated energy efficiency and conservation measures. These initiatives include minimum efficiency performance standards and energy efficiency labels for electrical appliances. Several other efforts have also been made at the institutional level such as establishment of the National Energy Efficiency and Conservation Authority (NEECA) for promotion and implementation of energy efficiency and conservation. However, in order to achieve the paybacks of the initiated measures, understanding consumer behavior, perspective, and intentions for adopting these measures is of core importance. Past empirical studies have employed extended models of existing theories by including additional constructs in green purchase and energy saving behavior. In this context, the applicability of extended models of theory of planned behavior (TPB) has been verified by researchers $[17,18]$. A recent study used a combination of TPB and the technology readiness index to assess purchase intention of energy saving products in Pakistan [19]. Similarly, Waris and Ahmed [20] used the modified version of TPB to study antecedents of consumers intentions to purchase energy efficient household appliances. Another study by Waris and Hameed [21] used extended TPB model and found environmental concerns, knowledge of eco-labels and perceived effectiveness as significant determinants of purchase intentions for energy saving appliances in Pakistan. The author suggests inclusion of psychological, technological, or other variables such as government and media impact on people in shaping their behavior for energy efficient choices.

In the extant body of literature, the studies related to consumers' behavior towards efficient utilization of energy have been discussed with inclusion of constructs linked to environmental behavior $[8,14,22]$, socio-economic characteristics $[23,24]$, and financial drivers $[25,26]$. In general, these studies highlighted the importance of effective information 
campaigns to develop consumers' acceptance towards energy efficiency and conservation measures. However, there is scarcity of research that investigates the impact of policy information campaigns on purchase intentions of the consumers towards energy efficient appliances in energy deficient emerging economies. It is pertinent to mention that the governments of the energy deficient developing countries such as India and Pakistan also appeal for the use of electricity efficient appliances and electricity saving measures with moral tag lines such as Save Electricity-Build Nation (i.e., India Bijli Bachao-Desh Banano) $[27,28]$. In addition, one of the most popular and successful energy saving initiative in developing countries has been the replacement of incandescent bulbs with energy efficient compact fluorescent lamps (CFL's), leading consumers to have experience of using EEA [29].

Hence, to narrow down this literature gap, this study uses an extended model of TPB by incorporating 'policy information campaigns', 'moral norm,' and 'past purchase experience' to investigate behavioral intentions. The objective of the study is to better understand the determinants affecting consumers' intentions towards the purchase of energy efficient household appliances in context of a developing country i.e., Pakistan. Furthermore, the study intends to propose policy initiatives to guide policy development for fostering consumers' adoption of energy efficient appliances in the country.

The remainder of the paper is organized as follows: Section 2 explains the theoretical framework and hypotheses development. Section 3 provides a brief overview of the quantitative research methodology opted for the study. Results and Discussion are presented in Section 4. Section 5 outlines proposed policy guidelines for promoting energy efficiency in households. Finally, concluding remarks and research limitations are provided in Section 6.

\section{Theoretical Framework and Hypotheses Development}

Behavioral theories and conceptual frameworks have been employed to investigate attitude and behavior of the consumers towards energy conservation and efficient utilization. Among behavioral theories, the theory of planned behavior formulated by Ajzen [30] has been the focus of the researchers to investigate attitude and behavior of the consumers towards energy efficiency and conservation [31,32]. A wide use of TBP has been witnessed in studying pro-environmental, energy saving, and renewable energy usage behaviors $[11,17,33]$. In addition, the robustness and predictability of TPB to determine purchase intention of the consumers under diverse circumstances has been established through extant body of literature [13,14,34,35]. Considering the fact, this study used an extended model of TPB to analyze intentions of the consumers towards the purchase of energy efficient appliances.

\subsection{Theory of Planned Behavior}

The basic hypothesis of the TPB is that intention is the only direct psychological determinant of behavior. It posits that behavioral intention is affected by the attitude, subjective norms, and perceived behavioral control. Hence, to understand individual behavior, it is required to understand the individual's attitude, subjective norms, and perceived behavioral control.

\subsubsection{Attitude}

Attitude is an inclination or propensity towards a thought, an individual, or a situation. It indicates general evaluation of the behavior of an individual resulting in a desirable outcome. According to TPB, attitude drives the intention which shapes human behavior. For instance, Yadav and Pathak [13] studied determinants of green purchase behavior and found positive influence of attitude on purchase intentions. In context of energy efficient appliances, a number of studies have affirmed that attitude strongly influences consumers' purchase intentions $[9,14,34]$. Hence, the following hypothesis is proposed on the basis of the positive relation between attitude and intentions towards the purchase of energy efficient appliances. 
Hypothesis 1 (H1). Attitude positively influence intentions towards the purchase of energy efficient household appliances.

\subsubsection{Subjective Norm}

Subjective norm is perceived social pressure to perform or not to perform [30]. Individuals tend to follow the conduct of others and comply with social practices. These practices are the 'guideline' rules or behavioral desires of a society that define what is regarded as normal and desirable [34]. Prior studies identified subjective norm as a significant predictor of intentions towards the purchase of energy saving appliances [36,37]. Therefore, the following hypothesis is proposed.

Hypothesis 2 (H2). Subjective norm has positive influence on intentions of the consumers towards the purchase of energy efficient household appliances.

\subsubsection{Perceived Behavioral Control}

Perceived behavioral control (PBC) refers to the ease or difficulty to carry out a behavior. It is determined by both the situational and internal factors that facilitate or restrain an individual from a specific behavior. For example, to adopt a new technology, the consumer will determine requirements in terms of effort and resources [33]. In context of energy efficient appliances, the associated convenience such as price incentives, availability of appliances, and credibility of energy efficiency labels are important considerations [24].

Wang et al. [38] measured perceived behavioral control in terms of price and availability in order to determine adoption intentions towards electric vehicles. The study confirmed positive influence of PBC on adoption intentions. Similarly, Wang et al. [11] measured perceived behavioral control as the 'perceived inconvenience' and 'economic benefits' associated with electricity saving behavior. Wang et al. [17] also reported the significant impact of PBC on energy saving behavior. Hence, the following hypothesis is proposed:

Hypothesis 3 (H3). Perceived behavioral control positively influences intentions towards the purchase of energy efficient household appliances.

\subsection{Inclusion of Additional Constructs}

The extant body of literature is evident that the inclusion of additional constructs in basic TPB model is valuable for comprehensive prediction of intentions [13]. Based on literature and opinion of the authors, this study implemented TPB with following three additional constructs to find intentions of the consumers towards the purchase of energy efficient appliances.

\subsubsection{Policy Information Campaigns}

Sufficient information and knowledge help individuals in making decisions. Individuals normally avoid uncertainties and the circumstances in which information is incomplete. Therefore, the public information campaigns are one of the tools to influence behavior by enhancing knowledge of the people about energy efficient choices. Ek and Söderholm [39] identified that comprehensive information about energy efficiency influences the consumers towards electricity saving. Reiss and White [40] conducted a study and concluded that information campaigns and conservation appeals reduced electricity demand in California.

Lack of information is one of the primary barriers in accepting new technology such as energy efficient appliances [41]. For instance, Yang and Zhao [26] discussed that the subsidies and incentives are ineffective if familiarization is insufficient. Kim [42] claimed that effective information campaigns can significantly influence decisions of the consumers. Joshi et al. [43] found that the lack of effective information campaigns increases uncertainty about energy efficient appliances, leading to failure of energy efficiency and conservation 
measures. Hence, policy formulations including pro-green energy programs and mass messages are critical to encourage volunteer adoption of green appliances [44]. Wang et al. [17] and Wang et al. [11] incorporated an information campaign in the TPB model and found a positive influence of information campaigns on energy saving behavior among Chinese residents. Based on the above discussion, we assume:

Hypothesis 4 (H4). Policy information campaigns positively influence intentions of the consumers towards the purchase of energy efficient appliances.

\subsubsection{Moral Norms}

Moral obligations refer to the feelings of an individual for performing a specific behavior in an ethical situation. Godin et al. [45] argued that moral norms greatly impact human intentions in comparison with attitude. Therefore, it is very likely that intentions based on moral norms will result in increased persistence and efforts to indulge in an action.

The inclusion of moral norms in TPB models serves as an added feature to determine behavior of the consumers in social and environmental context. Chen [46] examined moral belief about climate change and found positive relation between moral norms and energy saving behavior. Arpan et al. [47] found that moral norms influence response rate of the consumers towards energy efficiency programs. Tan et al. [14] conducted a study in Malaysia and identified moral norms as a meaningful predictor of intentions towards the purchase of energy efficient appliances. Based on the above discussion, the following hypothesis is proposed:

Hypothesis 5 (H5). Moral norms positively influence intentions of the consumers towards the purchase of energy efficient appliances.

\subsubsection{Past Purchase Experience}

Consumers learn from their experiences and therefore purchase intention is affected by past purchase experience [30]. Purchase experience is one of the features that provide better prediction of behavioral intentions [48]. Frederiks et al. [49] indicated that people generally stick to the action once opted, especially, when resources such as time and money are involved. Therefore, good experience can motivate an individual to purchase the same product again and again [34].

In the context of green purchasing, D'Souza et al. [50] mentioned that past experience of the consumers influence future purchases. In studying determinants of electricity saving behavior among Beijing residents, Wang et al. [11] concluded that past purchase experience affects electricity saving behavior. Similarly, Wang et al. [34] found past purchase experiences significantly influence intentions towards the purchase of energy efficient appliances in China. Considering the above findings, the following hypothesis is proposed:

Hypothesis 6 (H6). Past purchase experiences positively influence intentions towards the purchase of energy efficient appliances.

Based on the above mentioned hypotheses, the proposed research model with inclusion of additional constructs (policy information campaigns, moral norm, and past purchase experience) is presented in Figure 1. 


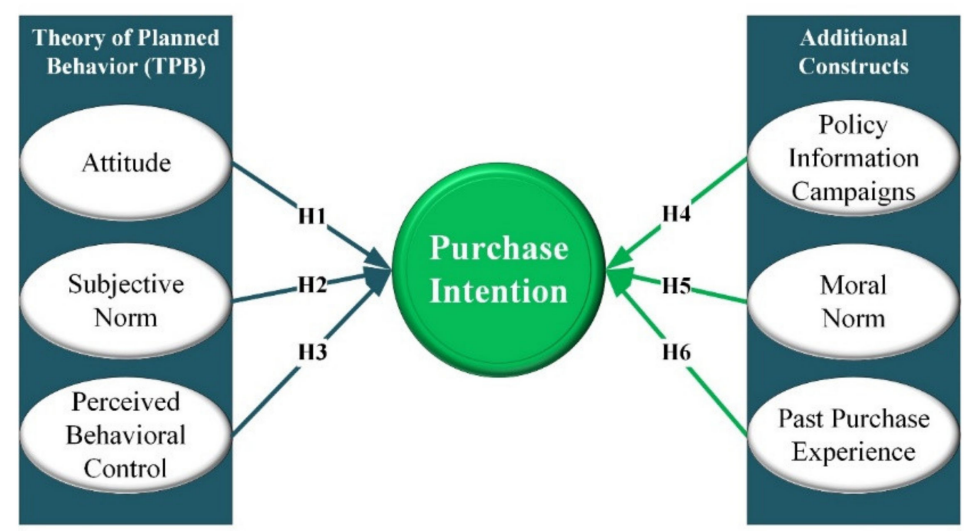

Figure 1. Research model with inclusion of three additional constructs in Theory of Planned Behavior (TPB).

\section{Methodology}

The quantitative research methodology was adopted for this study. Quantitative research has been favored by researchers to study purchase intentions due to its flexibility in data collection and handling, concerning statistical analysis, and generalizability of the findings for a broader population [51,52]. The survey questionnaire was initially designed in English and then translated to Urdu (national language) to be better understood by the respondents. A pilot survey was conducted for questionnaire validation. The necessary refinements in terms of the selection of words and flow of the items were made in light of the pilot survey. The respondents were given the choice to fill the questionnaire in their preferred language.

In Pakistan, the rural and urban divisions of the population represent significant difference in various aspects. These differences are not limited to general human development indexes but also pertain to expenditures and usage of electricity in both rural and urban settings. The urban households' expenditure on electricity mounts to $69.40 \%$ of the total household expenditure on fuel and lighting, while it covers only $38.61 \%$ for rural households [53]. Additionally, residents in urban and rural settings of Pakistan exhibit remarkable difference in terms of ownership of household appliances. According to Gallup Pakistan, Urban household are $34 \%$ more likely to own a television as compared to the rural households [54]. Hence, the unit of analysis in this study are individual household consumers aged 18 and above and belonging to urban and sub-urban regions of the country. For this purpose, the metropolitan cities namely Islamabad (capital), Rawalpindi and two of its neighboring cities Taxila and Wah-Cant were selected for data collection. IslamabadRawalpindi region is one of the largest metropolitan regions in Pakistan. In addition, the region is home to people belonging from most parts of the country.

The study employed a non-probability purposive sampling for data collection. The technique is deemed appropriate when it is difficult to gather a complete sampling frame. Purposive sampling also facilitates the theoretical generalizations of findings from the sample under consideration. The sample size is based on the evidence from [54] that suggests a ratio of five to ten responses per item in the study. Given the 21 items in the study, a minimum of 210 samples were required. A total of 571 self-administered questionnaires were distributed between Nov. 2018-Jan. 2019. The study recorded a 54.81\% response rate, with 313 filled questionnaires. Due to lack of complete information and inadequate response, a total of 24 responses questionnaires were discarded. The final sample of 289 respondents was considered for the analysis purposes. The demographic profiles of the respondents are given in Table 1. 
Table 1. Demographics of the respondents.

\begin{tabular}{cccc}
\hline Variable & Description & Frequency & Percentage \\
\hline \multirow{2}{*}{ Gender } & Male & 176 & $60.8 \%$ \\
& Female & 113 & $39.2 \%$ \\
Age (years) & Between 18-25 & 69 & $23.87 \%$ \\
& Between 26-35 & 116 & $40.13 \%$ \\
& Between 36-50 & 88 & $30.44 \%$ \\
& Above 50 & 16 & $5.53 \%$ \\
Monthly Income (PKR) & Less than 15,000 & 30 & $32.52 \%$ \\
& Between 15,000-30,000 & 94 & $30.10 \%$ \\
& Between 31,000-60,000 & 87 & $19.72 \%$ \\
& Between 61,000-91,000 & 57 & $7.26 \%$ \\
& Above 90,000 & 21 & $15.90 \%$ \\
& Lower secondary or below & 46 & $22.49 \%$ \\
& Higher secondary or equivalent & 65 & $48.44 \%$ \\
& Bachelor's degree or equivalent & 140 & $13.14 \%$ \\
& Master's degree or above & 38 & $27.68 \%$
\end{tabular}

Following appropriateness $[55,56]$, the constructs were measured on a five-point Likert scale ranging from strongly agree to strongly disagree $(5=$ strongly agree, $4=$ agree, $3=$ neutral, 2 = disagree, 1 = strongly disagree). The variables of this study were latent and the items to measure each latent variable were adopted from existing energy-related behavioral studies. The items were further modified to fit in the context of the current study. The measured items with references are provided in Table A1.

The survey based on self-reported data holds the risk of common method bias [57]. The fact that data for both the depended and independent variables are collected from the same sample at a specific time, increases the possibility of distortion of relationship among the constructs due to common method variance. The presence of common method bias inflates or deflates the correlations among factors and thus has potential to jeopardize the validity of findings from the study [58]. In order to address this problem, we performed Harman's single factor analysis to determine the variance for a single factor [59]. Harman's single factor test suggests a threshold value of less than $50 \%$ total variance for a single factor. Our result showed that the single factor variance accounted for $27 \%$ which is less than the Harman's single factor variance criterion. Hence, there is no threat of common method bias.

\section{Results}

In this study, partial least square structural equation modeling (PLS-SEM) has been employed to test the theoretical model using smartPLS 3.0 [60]. PLS-SEM is advantageous due to its aptness for prediction, robustness, prevention of factor indeterminacy and inadmissible solutions, and its applicability for theory development [61]. Based on the PLS-SEM approach, a two-stage analytical procedure was performed for this study. First, we tested the measurement model (internal reliability and convergent validity). Next, we analyzed the structural model to test the hypothesized relationship as presented in the following sections.

\subsection{Model Validation}

The model was validated by examining internal reliability and convergent validity tests. The internal reliability was measured by Cronbach alpha and composite reliability tests. According to Hair Jr et al. [62], the recommended threshold value for both measures is 0.70 . Table 2 establishes that the values of all the constructs $(0.710-0.924)$ satisfy the criterion of internal reliability. 
Table 2. Internal reliability and convergent validity of the model.

\begin{tabular}{|c|c|c|c|c|c|}
\hline Construct & $\begin{array}{l}\text { Measurement } \\
\text { Item }\end{array}$ & Loadings & Cronbach's Alpha & $\begin{array}{l}\text { Composite } \\
\text { Reliability }\end{array}$ & $\begin{array}{l}\text { Average Variance } \\
\text { Extracted (AVE) }\end{array}$ \\
\hline \multirow{3}{*}{ Attitude } & ATT1 & 0.78 & \multirow{3}{*}{0.711} & \multirow{4}{*}{0.837} & \multirow{4}{*}{0.632} \\
\hline & ATT2 & 0.83 & & & \\
\hline & ATT3 & 0.79 & & & \\
\hline \multirow{3}{*}{ Subjective Norm } & SUB1 & 0.76 & \multirow{3}{*}{0.710} & & \\
\hline & SUB2 & 0.82 & & \multirow[t]{2}{*}{0.827} & \multirow[t]{2}{*}{0.620} \\
\hline & SUB3 & 0.80 & & & \\
\hline \multirow{3}{*}{$\begin{array}{c}\text { Perceived } \\
\text { Behavioral Control }\end{array}$} & PBC1 & 0.81 & \multirow{3}{*}{0.713} & \multirow{3}{*}{0.838} & \multirow{3}{*}{0.633} \\
\hline & $\mathrm{PBC} 2$ & 0.78 & & & \\
\hline & PBC3 & 0.80 & & & \\
\hline \multirow{3}{*}{$\begin{array}{l}\text { Policy Information } \\
\text { Campaigns }\end{array}$} & PIC1 & 0.88 & \multirow{3}{*}{0.763} & \multirow{3}{*}{0.864} & \multirow{3}{*}{0.680} \\
\hline & PIC2 & 0.85 & & & \\
\hline & PIC3 & 0.76 & & & \\
\hline \multirow{3}{*}{ Moral Norm } & MRN1 & 0.91 & \multirow{3}{*}{0.924} & \multirow{3}{*}{0.951} & \multirow{3}{*}{0.867} \\
\hline & MRN2 & 0.90 & & & \\
\hline & MRN3 & 0.92 & & & \\
\hline \multirow{3}{*}{$\begin{array}{l}\text { Past Purchase } \\
\text { Experience }\end{array}$} & PPE1 & 0.82 & \multirow{3}{*}{0.742} & \multirow{3}{*}{0.855} & \multirow{3}{*}{0.664} \\
\hline & PPE2 & 0.90 & & & \\
\hline & PPE3 & 0.74 & & & \\
\hline \multirow{3}{*}{ Purchase Intention } & PI1 & 0.83 & \multirow{3}{*}{0.722} & \multirow{3}{*}{0.843} & \multirow{3}{*}{0.641} \\
\hline & PI2 & 0.77 & & & \\
\hline & PI3 & 0.82 & & & \\
\hline
\end{tabular}

The convergent validity was evaluated using average variance criteria (AVE) against recommended value of 0.50 [62]. It can be seen from Table 2 that the values for average variance range from 0.620 to 0.867 . Similarly, the item loadings for each item ranging from 0.74 to 0.92 demonstrate that the adequate convergent validity of the model is achieved.

Discriminant validity represents the extent of distinctiveness of the constructs in the model. According to Fornell and Larcker [63], the square root of the AVE shall be greater than its correlation with other constructs. Table 3 depicts that the values obtained by the square of correlation for each construct is less than the square root of the AVE. Hence, it is concluded that the model supports the discriminant validity indicating uniqueness of each construct.

Table 3. Correlation among the constructs.

\begin{tabular}{|c|c|c|c|c|c|c|c|}
\hline Construct & Attitude & $\begin{array}{l}\text { Moral } \\
\text { Norms }\end{array}$ & $\begin{array}{c}\text { Past } \\
\text { Purchase } \\
\text { Experience }\end{array}$ & $\begin{array}{c}\text { Perceived } \\
\text { Behavioral } \\
\text { Control }\end{array}$ & $\begin{array}{l}\text { Purchase } \\
\text { Intention }\end{array}$ & $\begin{array}{c}\text { Policy } \\
\text { Information } \\
\text { Campaigns }\end{array}$ & $\begin{array}{l}\text { Subjective } \\
\text { Norm }\end{array}$ \\
\hline Attitude & 0.795 & & & & & & \\
\hline Moral Norms & 0.465 & 0.931 & & & & & \\
\hline $\begin{array}{l}\text { Past Purchase } \\
\text { Experience } \\
\text { Perceived }\end{array}$ & 0.351 & 0.238 & 0.815 & & & & \\
\hline $\begin{array}{c}\text { Behavioral } \\
\text { Control }\end{array}$ & 0.423 & 0.238 & 0.389 & 0.796 & & & \\
\hline $\begin{array}{c}\text { Purchase } \\
\text { Intention } \\
\text { Policy }\end{array}$ & 0.562 & 0.386 & 0.457 & 0.481 & 0.80 & & \\
\hline $\begin{array}{l}\text { Information } \\
\text { Campaigns }\end{array}$ & 0.379 & 0.25 & 0.293 & 0.208 & 0.29 & 0.784 & \\
\hline Subjective Norm & 0.497 & 0.425 & 0.396 & 0.28 & 0.46 & 0.199 & 0.825 \\
\hline
\end{tabular}


The value of the coefficient of determination $\mathrm{R}^{2}$ indicates explanatory power of the model. The value of $\mathrm{R}^{2}$ is improved from 0.376 to 0.462 for the proposed TPB model (with additional constructs) as compared to the original TPB framework, indicating superiority of the extended framework over the traditional TPB model. The value of $\mathrm{R}^{2}$ implies that $46.2 \%$ of the variance in purchase intentions for energy efficient appliances can be explained by the proposed research model.

\subsection{Hypotheses Analysis and Discussion}

The hypotheses were tested using a bootstrapping function with 5000 bootstrap samples in smartPLS. The recommended critical values of $\mathrm{t}$-test (significance level $=5 \%$ ) were applied [62]. The value of the path coefficient $(\beta)$ indicates the strength of the influence of independent variables on dependent variable. The summary of hypotheses testing results is presented in Table 4.

Table 4. Hypotheses analysis.

\begin{tabular}{|c|c|c|c|c|c|}
\hline Hypotheses & Relationship & $\begin{array}{c}\text { Path } \\
\text { Coefficient }(\beta)\end{array}$ & T-Statistics & $p$-Values & Result \\
\hline Attitude & $\mathrm{ATT} \Rightarrow \mathrm{PI}$ & 0.278 & 3.477 & 0.001 * & Supported \\
\hline $\begin{array}{l}\text { Subjective } \\
\text { Norm }\end{array}$ & $\mathrm{SUB} \Rightarrow \mathrm{PI}$ & 0.035 & 0.565 & 0.572 & Not Supported \\
\hline $\begin{array}{c}\text { Perceived } \\
\text { Behavioral } \\
\text { Control } \\
\text { Policy }\end{array}$ & $\mathrm{PBC} \Rightarrow \mathrm{PI}$ & 0.223 & 2.786 & $0.006^{*}$ & Supported \\
\hline $\begin{array}{l}\text { Information } \\
\text { Campaigns }\end{array}$ & $\mathrm{PIC} \Rightarrow \mathrm{PI}$ & 0.137 & 2.01 & $0.045^{*}$ & Supported \\
\hline Moral Norms & $\mathrm{MRN} \Longrightarrow \mathrm{PI}$ & 0.120 & 1.50 & 0.134 & Not Supported \\
\hline $\begin{array}{l}\text { Past Purchase } \\
\text { Experience }\end{array}$ & $\mathrm{PPE} \Longrightarrow \mathrm{PI}$ & 0.185 & 2.986 & 0.002 * & Supported \\
\hline
\end{tabular}

For H1, the values of $\beta$-coefficient $(0.278)$ and $p(0.001)$ indicate attitude as the primary determinant of purchase intention towards energy efficient appliances. This situation confirms that favorable attitude of the consumers towards energy efficient appliances motivate them to purchase these appliances. This outcome is consistent with previous studies by Greaves et al. [64], Ha and Janda [36], and Wang et al. [34]. Waris and Hameed [65] also found attitude as a significant determinant of purchase intentions for energy efficient appliances in Pakistan's context. Attitude can be developed or modified by promoting a positive image of the act among individuals [13]. Likewise, positive attitude towards energy efficient appliances can be enhanced by creating more awareness among people.

For $\mathrm{H} 2$, contrary to our expectations, the values of $\beta$-coefficient $(0.035)$ and $p(0.572)$ suggest insignificant impact of subjective norms on purchase intentions. This outcome is in line with the findings of Tan et al. [14], Rezaei and Ghofranfarid [66], however, contradict with findings of the studies conducted by Yadav and Pathak [13] and Wang et al. [17]. This result implies that consumers are not easily influenced by opinion of others while making purchase decision for energy efficient appliances. Ali et al. [19] notes that excessive opinion from others can potentially cause negatively influence on the purchase intentions. In addition, Gao et al. [67] argued that individuals who are more educated are more rational and have their own opinion. As respondents of this study were mostly educated, it might be one of the reasons of insignificance.

For H3, the values of $\beta$-coefficient (0.0223) and $p$ (0.006) affirm the significance of perceived behavioral control on purchase intentions. This finding is consistent with studies conducted by Waris and Ahmed [20], Wang et al. [38], and Wang et al. [11]. Previous studies mentioned reluctance of the consumers in purchasing energy efficient appliances as compared to conventional appliances due to high price [68]. This signifies the importance of reasonable price and ease of availability so that less time and effort is required by the consumer to purchase these appliances. Putting it briefly, consumers having capacity to 
buy energy efficient appliances, are more likely to buy it. High prices as compared to consumers' expectations and hurdles in the process to find these appliances can undermine purchase intentions of the consumers.

For H4, the values of $\beta$-coefficient (0.137) and $p$ (0.045) establish that the policy information campaign is a significant determinant of purchase intention towards energy efficient appliances. The results are in line with the studies of Wang et al. [11] and Wang et al. [17]. The results suggest that consumers are motivated by information campaigns. This scenario signifies the importance of information campaigns towards the promotion of energy efficient appliances. Hence, apart from introducing policy instruments like energy efficiency labels and minimum efficiency standards, an effective communication of these initiatives is equally important. Therefore, in efforts to encourage and support the purchase of energy efficient appliances, mass media channels should be used to raise awareness about initiated measures and associated benefits for using energy efficient appliances.

For $\mathrm{H} 5$, the values of $\beta$-coefficient $(0.12)$ and $p(0.134)$ identify that moral norms are not a significant determinant of purchase intention. This outcome is contradictory to the findings of Tan et al. [14]. Ito et al. [69] also asserted that moral suasion stimulates behavioral change towards energy conservation only for a short period of time, while behavioral change due to economic incentives is larger and persistent. Although the responses against individual constructs demonstrate concerns of the consumers towards electricity saving and environmental protection, the consumers do not feel morally obliged to purchase energy efficient appliances. This could be because of the misunderstanding about the role and contribution of energy efficient appliances towards energy saving, economic benefits, and environmental protection. For instance, in Pakistan, there have been persistent moral campaigns to motivate consumers for saving electricity with the slogan "save electricity: for yourself, for your nation". However, this moral motivation towards electricity saving through energy efficient appliances could not sustain in front of the trust deficit caused due to no apparent economic benefit.

For H6, the values of $\beta$-coefficient (0.185) and $p(0.002)$ show positive influence of past experiences on purchase intentions of the consumers. Wang et al. [34] also identified past purchase experience as a significant contributor of purchase intentions towards efficient appliances in China. The reason of this strong influence is due to the great popularity of compact fluorescent lamps (CFLs) commonly referred as 'energy savers' among respondents. CFLs received great popularity against traditional bulbs because of lower energy consumption and longer lifespan. To know about the significant contribution towards the success of CFLs and the impact of this past experience on future purchase, the constructs of past purchase experience were categorized into (i) comfort and convenience of using these appliances, (ii) and economic benefits in terms of electricity cost reduction. From results, this positive (economic and convenience) experience of the consumers can be the reason of shaping positive perception towards energy efficient appliances.

\section{Policy Implications}

The results presented in previous sections have important practical implications to establish an energy efficiency environment. The inclusion of additional constructs improved explanatory power of the TPB framework to better comprehend the determinants of consumers purchase intentions towards energy efficient appliances. Furthermore, the outcomes of this study provide useful insights for policy makers and marketers to develop suitable strategies for promoting energy efficient products.

The result demonstrates that attitude and information campaigns positively influence purchase intentions of the consumers. Therefore, efforts must be done to sensitize consumers for a favorable attitude towards these appliances through impactful campaigns. However, moral norms are found to have insignificant impact on purchase intentions. This implies that while designing campaigns, the financial benefits associated with energy efficient appliances must be highlighted as they may evoke improved response from the consumers. Moreover, the significant impact of behavioral control (price and availability 
of appliances) to shape behavioral intentions signifies the need for reasonable price and fiscal incentives to attract consumers towards energy efficient appliances. Hence, it can be inferred that a structured policy of incentives and replacement (including flexible and lucrative schemes for consumers and manufacturers) pave the way for an energy efficient environment.

The development of an effective policy and focus by the government towards its implementation are vital to establish an energy efficient environment. Based on results presented in the previous section, recommendations for the development of an effective energy efficiency policy are structured in this section. The summary of the recommendations including constituents of awareness, incentives, replacement, and other policy initiatives is presented in Figure 2.

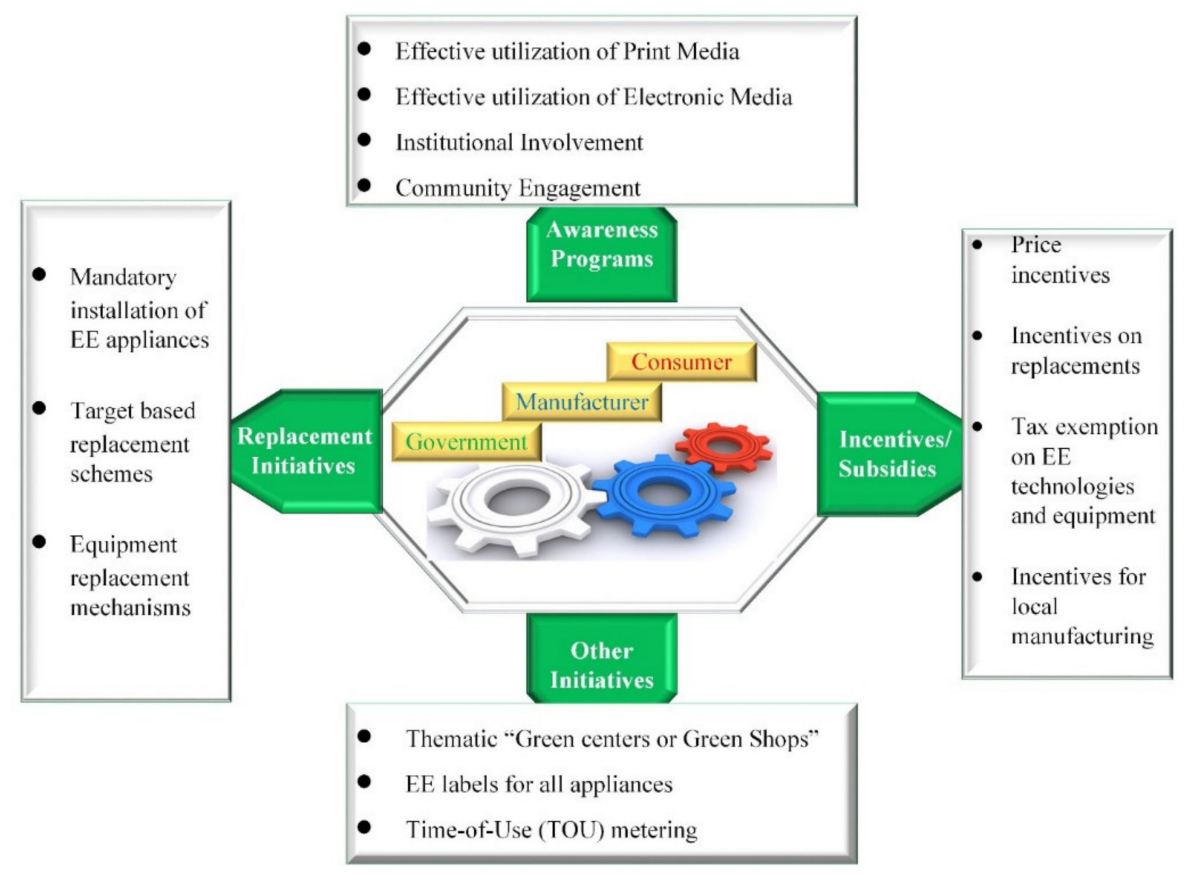

Figure 2. Policy initiatives to foster adoption of energy efficient appliances (EEA).

The details of the constituents of awareness, incentives, replacement, and other policy initiatives are discussed in the following sections.

\subsection{Constituents of Awareness Policy}

The awareness plan comprises effective utilization of print and electronic media platforms along with the active involvement of manufacturers, institutions, and community.

\subsubsection{Effective Use of Print Media}

Newspaper, billboards, and promotional flyers are the most effective and economical print media channels being practiced. It has been observed that consumers normally follow what they come to know and avoid to spend time on gathering information. Hence, an effective use of print media to provide on hand information is useful to enhance awareness about energy efficient appliances.

\subsubsection{Effective Use of Electronic Media}

Internet and social media is established as an easy, fast, and cost-effective platform for advertisement. Because of its effectiveness, accessibility, and real time information sharing, the government can use Internet and social media as a primary advertising tool to enhance awareness among consumers. Similarly, well-designed TV and radio advertisements can 
cultivate a lasting and favorable image in mind of the consumers. Mobile phone SMS services can also be used for promoting energy efficient household appliances.

\subsubsection{Community Engagement}

Community engagement can be effective to disseminate information. The government and administration can organize a committee comprising key personnel from the community to inform and motivate towards energy efficient appliances through day to day interactions.

\subsubsection{Institutional Involvement}

Institutional infrastructure can be useful in the development of green energy basis. In this context, the government needs to mobilize administrative, technical, and academic institutions to promote energy saving behavior. Arrangement of awareness conferences and seminars can also be helpful in developing a sense of responsibility and moral obligation towards energy conservation programs. Moreover, the information related to energy conservation, environmental and natural resources protection should be made an integral part of the syllabus. A similar policy is being implemented by the Bureau of Energy Efficiency in India (BEE) [70].

\subsection{Constituents of Incentives Policy}

Price and replacement incentives along with promotion of local manufacturing facilities for energy efficient appliances can help in fostering the implementation of an energy efficient environment.

\subsubsection{Price and Replacement Incentives}

Price incentives such as easy installments with $0 \%$ markup on purchase, and opportunity for replacing conventional appliances with energy efficient appliances may enhance intentions of the consumers towards the purchase of energy efficient appliances. Award schemes for the retailers including tax exemption for selling more energy efficient appliances can also be helpful. Similarly, introduction of incentives to consumers on reducing electricity consumption using energy efficient appliances can also foster an energy efficient environment.

\subsubsection{Incentives to Promote Local Manufacturing}

The development of the local appliances manufacturing industry will increase availability of energy efficient appliances. Hence, a policy can be devised to promote local manufacturing and startups by providing technical assistance, fiscal incentives, tax exemptions on importing energy efficient technologies and related equipment. In this regard, fair transfer of associated benefits to all stakeholders is key and must be ensured.

\subsubsection{Constituents of Replacement Policy}

The replacement policy comprises stepwise replacement of traditional appliances with energy efficient appliances in domestic and commercial sectors. Government institutions should start target-based replacement of ordinary appliances in offices, streets, schools, universities, and other public places. The initiative then can be expanded to private and residential sectors. Similarly, redesigning of building codes by adding provision for installing EEA, and inducing newly build housing societies responsible for taking energy efficiency measures can help in developing the green environment.

\subsection{Other Policy Initiatives}

The scope of energy efficiency standards and label schemes should be expanded to all electrical and electronics appliances. Though manufacturers of air-conditioners and refrigerators claim to be energy efficient, however, they do not highlight energy saving 
effect as the primary attribute which may create uncertainty in the consumer's mind for the energy efficiency aspect.

Similarly, thematic shops with the name of "green shops" or "green centers" can be developed for awareness and availability of EEA. The representatives of these shops can provide necessary information about energy efficient appliances and related benefits. In addition, these shops can be used as replacement centers of traditional appliances with energy efficient appliances.

The adoption of net metering and TOU (time-of-use) tariff schemes provide real-time energy consumption patterns. From these energy consumption patterns, the policies and frameworks can be developed to influence consumption behavior towards energy efficiency. Hence, the removal of hurdles in implementation of TOU and net metering can be helpful in developing sustainable energy environment.

\section{Conclusions and Future Recommendations}

This study extends the research in investigating the behavior of consumers towards the purchase of energy efficient appliances from a developing country perspective [19-21]. The theory of planned behavior has been used with incorporation of additional constructs including policy information campaigns, moral norms, and past purchase experience. The extended model is unique and tested in a developing country context i.e., Pakistan. Based on literature, six hypotheses were constructed and analyzed through partial least square method. The findings revealed that attitude, policy information campaigns, perceived behavioral control, and past purchase experience exhibit a positive relationship with purchase intentions towards energy efficient appliances. However, moral and subjective norms were found insignificant in influencing purchase intention of the consumers. The results depict that the inclusion of additional constructs improved explanatory power of the TPB framework confirming the applicability of the extended model to study purchase intentions.

Based on findings from the study, we present guidelines for the development of an energy efficient environment. As developing countries are increasingly pushing for promoting the use of energy efficient appliances, the proposed guidelines can aid policy incumbents in strengthening the energy efficiency initiatives. These policy guidelines comprise awareness, incentives, and replacement programs for the development of an energy efficient and green environment. In particular, findings suggest that in order to influence consumers' purchase intention, it is pertinent to incentivize, promote, and communicate the benefits and unique aspects of energy efficient appliances using smart marketing communication channels (social media platforms). The positive attitude towards energy efficient appliances and positive experience of using CFLs provides a unique opportunity to drive energy efficient choices/appliances in households.

It is worthy to note few research limitations of this study. The research is based on a survey from Pakistani residents and can be further expanded with responses from a more diverse population and inclusion of more psychological variables to have deeper insight into consumers' behavioral intentions. In addition, future studies can make use of longitudinal data to examine actual purchase behavior of energy efficient appliances. Furthermore, the extended model can be opted as a baseline to predict and compare other green purchase behaviors such as eco-friendly appliances, intentions to visit a green hotel, or green food consumption. However, despite limitations, this study is a key step towards improved understanding of consumers' behavior regarding energy efficiency, especially, in context of Pakistan.

Author Contributions: M.R.A. and M.S. conceptualized and wrote the first draft of the manuscript. M.R.A. and M.S. collected and analyzed data. M.R.A., M.S., and M.A. designed the research protocol and methods. All authors reviewed and commented on subsequent drafts of the manuscript. All authors have read and agreed to the published version of the manuscript.

Funding: This research received no external funding. 
Informed Consent Statement: Informed consent was obtained from all subjects involved in the study.

Data Availability Statement: Data will be made available upon request.

Conflicts of Interest: The authors declare that they have no conflicts of interest.

\section{Appendix A}

Table A1. Items to measure latent variables.

\begin{tabular}{|c|c|c|c|}
\hline Constructs & Items & & References \\
\hline Attitude & $\begin{array}{l}\text { ATT1 } \\
\text { ATT2 } \\
\text { ATT3 }\end{array}$ & $\begin{array}{l}\text { It is important to me whether a household appliance is energy efficient or not. } \\
\text { I am interested in reducing the energy consumption of my household appliances. } \\
\text { I am interested in learning about energy efficiency, conservation, and energy saving appliances. }\end{array}$ & {$[9,34,36]$} \\
\hline Moral Norm & $\begin{array}{l}\text { MR1 } \\
\text { MR2 } \\
\text { MR3 }\end{array}$ & $\begin{array}{l}\text { It is my moral responsibility to save electricity. } \\
\text { It is my moral responsibility to use energy efficient appliances. } \\
\text { It is my moral responsibility to contribute to environmental protection. }\end{array}$ & {$[36,71,72]$} \\
\hline Social Norm & $\begin{array}{l}\text { SOC1 } \\
\text { SOC2 } \\
\text { SOC3 }\end{array}$ & $\begin{array}{l}\text { My family is in favor of buying energy efficient appliances. } \\
\text { People whose opinion I value would prefer that I purchase energy efficient appliances. } \\
\text { My friend and colleagues would prefer that I purchase energy efficient appliances. }\end{array}$ & {$[14,73]$} \\
\hline Past Purchase & $\begin{array}{l}\text { PP1 } \\
\text { PP2 } \\
\text { PP3 }\end{array}$ & $\begin{array}{l}\text { There have been energy-saving appliances in my home from last } 5 \text { years. } \\
\text { I believe that buying an energy efficient appliance has resulted in increased comfort and } \\
\text { convenience for me. } \\
\text { I believe that using an energy efficient appliance resulted in electricity bill reduction. }\end{array}$ & [74] \\
\hline $\begin{array}{c}\text { Perceived } \\
\text { Behavioral Control }\end{array}$ & $\begin{array}{l}\text { PBC1 } \\
\text { PBC2 } \\
\text { PBC3 }\end{array}$ & $\begin{array}{l}\text { Price is an important consideration for me to purchase energy efficient appliances. } \\
\text { Time and effort is an important consideration for me to purchase energy efficient appliances. } \\
\text { Convenience in terms of availability, is an important consideration for me to purchase energy } \\
\text { efficient appliances }\end{array}$ & {$[34,75,76]$} \\
\hline Purchase Intention & $\begin{array}{l}\text { PI1 } \\
\text { PI2 } \\
\text { PI3 }\end{array}$ & $\begin{array}{l}\text { If I need to buy a household appliance, I intend to buy an energy efficient one. } \\
\text { I will make efforts to purchase energy efficient appliances. } \\
\text { I will shift from the use of traditional appliance to energy efficient appliances. }\end{array}$ & {$[8,9]$} \\
\hline
\end{tabular}

\section{References}

1. Lund, H. Renewable energy strategies for sustainable development. Energy 2007, 32, 912-919. [CrossRef]

2. Nejat, P.; Jomehzadeh, F.; Taheri, M.M.; Gohari, M.; Majid, M.Z.A. A global review of energy consumption, CO 2 emissions and policy in the residential sector (with an overview of the top ten CO 2 emitting countries). Renew. Sustain. Energy Rev. 2015, 43, 843-862. [CrossRef]

3. Chunekar, A.; Sreenivas, A. Towards an understanding of residential electricity consumption in India. Build. Res. Inf. 2019, 47, 75-90. [CrossRef]

4. Salam, R.A.; Amber, K.P.; Ratyal, N.I.; Alam, M.; Akram, N.; Muñoz, C.Q.G.; Márquez, F.P.G. An Overview on Energy and Development of Energy Integration in Major South Asian Countries: The Building Sector. Energies 2020, 13, 5776. [CrossRef]

5. Cabeza, L.F.; Ürge-Vorsatz, D.; McNeil, M.A.; Barreneche, C.; Serrano, S. Investigating greenhouse challenge from growing trends of electricity consumption through home appliances in buildings. Renew. Sustain. Energy Rev. 2014, 36, 188-193. [CrossRef]

6. Safarzadeh, S.; Rasti-Barzoki, M. A game theoretic approach for assessing residential energy-efficiency program considering rebound, consumer behavior, and government policies. Appl. Energy 2019, 233, 44-61. [CrossRef]

7. Frederiks, E.R.; Stenner, K.; Hobman, E.V.; Fischle, M. Evaluating energy behavior change programs using randomized controlled trials: Best practice guidelines for policymakers. Energy Res. Soc. Sci. 2016, 22, 147-164. [CrossRef]

8. Park, E.; Kwon, S.J. What motivations drive sustainable energy-saving behavior? An examination in South Korea. Renew. Sustain. Energy Rev. 2017, 79, 494-502. [CrossRef]

9. Nguyen, N.; Lobo, A.; Greenland, S. Energy efficient household appliances in emerging markets: The influence of consumers values and knowledge on their attitudes and purchase behaviour. Int. J. Consum. Stud. 2016, 41, 167-177. [CrossRef]

10. Li, Q.; Long, R.; Chen, H. Differences and influencing factors for Chinese urban resident willingness to pay for green housings: Evidence from five first-tier cities in China. Appl. Energy 2018, 229, 299-313. [CrossRef]

11. Wang, Z.; Zhang, B.; Yin, J.; Zhang, Y. Determinants and policy implications for household electricity-saving behaviour: Evidence from Beijing, China. Energy Policy 2011, 39, 3550-3557. [CrossRef]

12. Li, G.; Li, W.; Jin, Z.; Wang, Z. Influence of Environmental Concern and Knowledge on Households' Willingness to Purchase Energy-Efficient Appliances: A Case Study in Shanxi, China. Sustainability 2019, 11, 1073. [CrossRef]

13. Yadav, R.; Pathak, G.S. Determinants of Consumers' Green Purchase Behavior in a Developing Nation: Applying and Extending the Theory of Planned Behavior. Ecol. Econ. 2017, 134, 114-122. [CrossRef] 
14. Tan, C.-S.; Ooi, H.-Y.; Goh, Y.-N. A moral extension of the theory of planned behavior to predict consumers' purchase intention for energy-efficient household appliances in Malaysia. Energy Policy 2017, 107, 459-471. [CrossRef]

15. Siddique, S.; Wazir, R. A review of the wind power developments in Pakistan. Renew. Sustain. Energy Rev. 2016, 57, 351-361. [CrossRef]

16. Kazmi, H.; Mehmood, F.; Tao, Z.; Riaz, Z.; Driesen, J. Electricity load-shedding in Pakistan: Unintended consequences, opportunities and policy recommendations. Energy Policy 2019, 128, 411-417. [CrossRef]

17. Wang, Z.; Zhang, B.; Li, G. Determinants of energy-saving behavioral intention among residents in Beijing: Extending the theory of planned behavior. J. Renew. Sustain. Energy 2014, 6, 053127. [CrossRef]

18. Halder, P.; Pietarinen, J.; Havu-Nuutinen, S.; Pöllänen, S.; Pelkonen, P. The Theory of Planned Behavior model and students' intentions to use bioenergy: A cross-cultural perspective. Renew. Energy 2016, 89, 627-635. [CrossRef]

19. Ali, S.; Ullah, H.; Akbar, M.; Akhtar, W.; Zahid, H. Determinants of Consumer Intentions to Purchase Energy-Saving Household Products in Pakistan. Sustainability 2019, 11, 1462. [CrossRef]

20. Waris, I.; Ahmed, W. Empirical evaluation of the antecedents of energy-efficient home appliances: Application of extended theory of planned behavior. Manag. Environ. Qual. Int. J. 2020, 31, 915-930. [CrossRef]

21. Waris, I.; Hameed, I. An empirical study of consumers intention to purchase energy efficient appliances. Soc. Responsib. J. 2020. [CrossRef]

22. Prete, M.I.; Piper, L.; Rizzo, C.; Pino, G.; Capestro, M.; Mileti, A.; Pichierri, M.; Amatulli, C.; Peluso, A.M.; Guido, G. Determinants of Southern Italian households' intention to adopt energy efficiency measures in residential buildings. J. Clean. Prod. 2017, 153, 83-91. [CrossRef]

23. Mills, B.; Schleich, J. What's driving energy efficient appliance label awareness and purchase propensity? Energy Policy 2010, 38, 814-825. [CrossRef]

24. Gaspar, R.; Antunes, D. Energy efficiency and appliance purchases in Europe: Consumer profiles and choice determinants. Energy Policy 2011, 39, 7335-7346. [CrossRef]

25. Azar, E.; Al Ansari, H. Framework to investigate energy conservation motivation and actions of building occupants: The case of a green campus in Abu Dhabi, UAE. Appl. Energy 2017, 190, 563-573. [CrossRef]

26. Yang, S.; Zhao, D. Do subsidies work better in low-income than in high-income families? Survey on domestic energy-efficient and renewable energy equipment purchase in China. J. Clean. Prod. 2015, 108, 841-851. [CrossRef]

27. Dhingra, N.; Walia, A.; Mukherjee, P. In Measuring the impact of India's standard and labeling program. In Proceedings of the International Energy Policies \& Programmes Evaluation Conference, Amsterdam, The Netherlands, 7 June 2016; pp. 7-9.

28. Ali, S.; Anjum Shah, N. Electricity Crisis in Pakistan: Reception \& Adoption of Energy Saving Campaign Messages by PEPCO. Pak. J. Soc. Sci. 2012, 32.

29. Sarkar, A.; Singh, J. Financing energy efficiency in developing countries-Lessons learned and remaining challenges. Energy Policy 2010, 38, 5560-5571. [CrossRef]

30. Ajzen, I. The Theory of Planned Behavior. Organ. Behav. Human Decis. Proces. 2014, 50, 179-211. [CrossRef]

31. Scott, F.; Jones, C.R.; Webb, T.L. What do people living in deprived communities in the UK think about household energy efficiency interventions? Energy Policy 2014, 66, 335-349. [CrossRef]

32. Botetzagias, I.; Malesios, C.; Poulou, D. Electricity curtailment behaviors in Greek households: Different behaviors, different predictors. Energy Policy 2014, 69, 415-424. [CrossRef]

33. Alam, S.S.; Hashim, N.H.N.; Rashid, M.; Omar, N.A.; Ahsan, N.; Ismail, D. Small-scale households renewable energy usage intention: Theoretical development and empirical settings. Renew. Energy 2014, 68, 255-263. [CrossRef]

34. Wang, Z.; Wang, X.; Guo, D. Policy implications of the purchasing intentions towards energy-efficient appliances among China's urban residents: Do subsidies work? Energy Policy 2017, 102, 430-439. [CrossRef]

35. Albayrak, T.; Aksoy, S.; Caber, M. The effect of environmental concern and scepticism on green purchase behaviour. Market. Intell. Plan. 2013, 31, 27-39. [CrossRef]

36. Ha, H.-Y.; Janda, S. Predicting consumer intentions to purchase energy-efficient products. J. Consum. Market. 2012, 29, 461-469. [CrossRef]

37. Hori, S.; Kondo, K.; Nogata, D.; Ben, H. The determinants of household energy-saving behavior: Survey and comparison in five major Asian cities. Energy Policy 2013, 52, 354-362. [CrossRef]

38. Wang, S.; Fan, J.; Zhao, D.; Yang, S.; Fu, Y. Predicting consumers' intention to adopt hybrid electric vehicles: Using an extended version of the theory of planned behavior model. Transportation 2014, 43, 123-143. [CrossRef]

39. Ek, K.; Söderholm, P. The devil is in the details: Household electricity saving behavior and the role of information. Energy Policy 2010, 38, 1578-1587. [CrossRef]

40. Reiss, P.C.; White, M.W. What changes energy consumption? Prices and public pressures. RAND J. Econ. 2008, 39, 636-663. [CrossRef]

41. Kallbekken, S.; Saelen, H.; Hermansen, E.A.T. Bridging the Energy Efficiency Gap: A Field Experiment on Lifetime Energy Costs and Household Appliances. J. Consum. Policy 2013, 36, 1-16. [CrossRef]

42. Kim, K.-H. In Overview on Public Benefit Campaigns to Promote Energy Conservation and Energy Efficiency. In Proceedings of the United Nations Forum on Energy Efficiency and Energy Security: Taking Collaborative Action on Mitigation Climate Change, Seoul, Koera, 17-18 December 2007. 
43. Joshi, G.Y.; Sheorey, P.A.; Gandhi, A.V. Analyzing the barriers to purchase intentions of energy efficient appliances from consumer perspective. Benchmarking: Int. J. 2019, 26, 1565-1580. [CrossRef]

44. Sangroya, D.; Nayak, J.K. Factors influencing buying behaviour of green energy consumer. J. Clean. Prod. 2017, 151, $393-405$. [CrossRef]

45. Godin, G.; Conner, M.; Sheeran, P. Bridging the intention-behaviour gap: The role of moral norm. Br. J. Soc. Psychol. 2005, 44, 497-512. [CrossRef] [PubMed]

46. Chen, M.-F. Extending the theory of planned behavior model to explain people's energy savings and carbon reduction behavioral intentions to mitigate climate change in Taiwan-moral obligation matters. J Clean. Prod. 2016, 112, 1746-1753. [CrossRef]

47. Arpan, L.M.; Barooah, P.; Subramany, R. The Role of Values, Moral Norms, and Descriptive Norms in Building Occupant Responses to an Energy-Efficiency Pilot Program and to Framing of Related Messages. Appl. Environ. Educ. Commun. 2015, 14, 23-32. [CrossRef]

48. Conner, M.; Armitage, C.J. Extending the Theory of Planned Behavior: A Review and Avenues for Further Research. J. Appl. Soc. Psychol. 1998, 28, 1429-1464. [CrossRef]

49. Frederiks, E.R.; Stenner, K.; Hobman, E.V. Household energy use: Applying behavioural economics to understand consumer decision-making and behaviour. Renew. Sustain. Energy Rev. 2015, 41, 1385-1394. [CrossRef]

50. D'Souza, C.; Taghian, M.; Lamb, P.; Peretiatkos, R. Green products and corporate strategy: An empirical investigation. Soc. Bus. Rev. 2006, 1, 144-157. [CrossRef]

51. Wekeza, S.V.; Sibanda, M. Factors Influencing Consumer Purchase Intentions of Organically Grown Products in Shelly Centre, Port Shepstone, South Africa. Int. J. Environ. Res. Public Heal. 2019, 16, 956. [CrossRef]

52. Hua, L.; Wang, S. Antecedents of Consumers' Intention to Purchase Energy-Efficient Appliances: An Empirical Study Based on the Technology Acceptance Model and Theory of Planned Behavior. Sustainability 2019, 11, 2994. [CrossRef]

53. Rafique, M.; Rehman, S.; Alhems, L.M. Developing zero energy and sustainable villages-A case study for communities of the future. Renew. Energy 2018, 127, 565-574. [CrossRef]

54. Pakistan, G. Pakistan Social and Living Measurements Survey | Home Appliances; Pakistan Bureau of Statistics: Islamabad, Pakistan, 2020.

55. Mostafa, M.M. Antecedents of Egyptian consumers' green purchase intentions: A hierarchical multivariate regression model. J. Int. Consum. Market. 2006, 19, 97-126. [CrossRef]

56. Paul, J.; Modi, A.G.; Patel, J.D. Predicting green product consumption using theory of planned behavior and reasoned action. J. Retail. Consum. Serv. 2016, 29, 123-134. [CrossRef]

57. Kamakura, W.A. Common Methods Bias; Wiley: Amsterdam, The Netherlands, 2010.

58. Spector, P.E.; Rosen, C.C.; Richardson, H.A.; Williams, L.J.; Johnson, R.E. A New Perspective on Method Variance: A MeasureCentric Approach. J. Manag. 2017, 45, 855-880. [CrossRef]

59. Harman, H.H. Modern Factor Analysis; University of Chicago Press: Chicago, IL, USA, 1976.

60. Ringle, C.M.; Wende, S.; Becker, J.-M. SmartPLS 3; SmartPLS GmbH: Boenningstedt, Germany, 2015.

61. Fornell, C.; Bookstein, F.L. Two structural equation models: LISREL and PLS applied to consumer exit-voice theory. J. Market. Res. 1982, 19, 440-452. [CrossRef]

62. Hair, J.F., Jr.; Hult, G.T.M.; Ringle, C.; Sarstedt, M. A Primer on Partial Least Squares Structural Equation Modeling (PLS-SEM); Sage Publications: Thousand Oaks, CA, USA, 2016.

63. Fornell, C.; Larcker, D.F. Structural Equation Models with Unobservable Variables and Measurement Error: Algebra and Statistics. J. Mark. Res. 1981, 18, 382-388. [CrossRef]

64. Greaves, M.; Zibarras, L.D.; Stride, C. Using the theory of planned behavior to explore environmental behavioral intentions in the workplace. J. Environ. Psychol. 2013, 34, 109-120. [CrossRef]

65. Waris, I.; Hameed, I. Promoting environmentally sustainable consumption behavior: An empirical evaluation of purchase intention of energy-efficient appliances. Energy Effic. 2020, 13, 1653-1664. [CrossRef]

66. Rezaei, R.; Ghofranfarid, M. Rural households' renewable energy usage intention in Iran: Extending the unified theory of acceptance and use of technology. Renew. Energy 2018, 122, 382-391. [CrossRef]

67. Gao, L.; Wang, S.; Li, J.; Li, H. Application of the extended theory of planned behavior to understand individual's energy saving behavior in workplaces. Resour. Conserv. Recycl. 2017, 127, 107-113. [CrossRef]

68. Young, W.; Hwang, K.; McDonald, S.; Oates, C.J. Sustainable consumption: Green consumer behaviour when purchasing products Sustain. Dev. 2010, 18, 20-31. [CrossRef]

69. Ito, K.M.; Ida, T.M.; Tanaka, M.M. Moral Suasion and Economic Incentives: Field Experimental Evidence from Energy Demand. SSRN Electron. J. 2018, 10, 240-267. [CrossRef]

70. Sahoo, S.K.; Varma, P.; Lall, K.P.; Talwar, C.K. Energy efficiency in India: Achievements, challenges and legality. Energy Policy 2016, 88, 495-503. [CrossRef]

71. Akhtar, N. Assessing Determinants of Consumers' Energy Conservation Behavior in Pakistan. Ph.D. Thesis, Capital University of Science and Technology, Islamabad, Pakistan, 2017.

72. Kaiser, F.G. A moral extension of the theory of planned behavior: Norms and anticipated feelings of regret in conservationism. Pers. Individ. Differ. 2006, 41,71-81. [CrossRef] 
73. Chen, M.-F.; Tung, P.-J. Developing an extended Theory of Planned Behavior model to predict consumers' intention to visit green hotels. Int. J. Hosp. Manag. 2014, 36, 221-230. [CrossRef]

74. Chen, Y.-S. Towards green loyalty: Driving from green perceived value, green satisfaction, and green trust. Sustain. Dev. 2010, 21, 294-308. [CrossRef]

75. Arkesteijn, K.; Oerlemans, L. The early adoption of green power by Dutch households: An empirical exploration of factors influencing the early adoption of green electricity for domestic purposes. Energy Policy 2005, 33, 183-196. [CrossRef]

76. Peterman, A.; Kourula, A.; Levitt, R.E. A roadmap for navigating voluntary and mandated programs for building energy efficiency. Energy Policy 2012, 43, 415-426. [CrossRef] 